\title{
The coupling of bacterial production and hydrography in the southern East China Sea: Spatial patterns in spring and fall
}

\author{
Fuh-Kwo Shiah ${ }^{\mathrm{a}, *}$, Kon-Kee Liu ${ }^{\mathrm{a}}$, Shuh-Ji Kao ${ }^{\mathrm{a}}$, \\ Gwo-Ching Gong ${ }^{\mathrm{b}}$
}

\author{
anstitute of Oceanography, National Taiwan University, P.O. Box 23-13, Taipei, Taiwan, ROC \\ ${ }^{\mathrm{b}}$ Department of Oceanography, National Taiwan Ocean University, Keelung, Taiwan, ROC
}

\begin{abstract}
Heterotrophic bacterial biomass, production and turnover rates were investigated in a transect across the continental shelf of the southern East China Sea during spring and fall. The sampling area covered different water types including nutrient-rich coastal and upwelling waters as well as oligotrophic Kuroshio waters. On area basis, bacterial biomass (IBB; 350-1200 $\mathrm{mgC} \mathrm{m}^{-2}$ ), production (IBP; $28-329 \mathrm{mgC} \mathrm{m}^{-2} \mathrm{~d}^{-1}$ ) and averaged turnover rates $\left(\mu=\mathrm{IBP} / \mathrm{IBB} ; 0.09-0.22 \mathrm{~d}^{-1}\right)$ in the coastal and upwelling areas were at least 2-fold of those in the Kuroshio waters. IBB, IBP and $\mu$ were positively correlated with primary production (IPP; 90-2133 $\mathrm{mgC} \mathrm{m}^{-2} \mathrm{~d}^{-1}$ ) and particulate organic carbon (IPOC; $1415-4682 \mathrm{mgC} \mathrm{m}^{-2}$ ) but showed a negative trend with temperature in the outer shelf area. While in the inner shelf $\left(<20^{\circ} \mathrm{C}\right)$, IBP and $\mu$ were positively correlated with temperature; the $Q_{10}$ value for bacterial $\mu$ was 3.12. These indicated that the spatial patterns of IBB, IBP and $\mu$ were more likely to be controlled by substrate supply and temperature interactively. Values of IBP : IPP ratio ranged $6-42 \%$ with an average of $22 \pm 10 \%$. Under the assumption of a growth efficiency of $20 \%$, shelf bacteria might consume carbon equivalent to almost $100 \%$ of the in situ daily particulate IPP. Dissolved organic carbon from non-phytoplankton and allochothonous sources might play a significant role in supporting bacterial carbon demand in the shelf area of the East China Sea. (C) 2000 Elsevier Science Ltd. All rights reserved.
\end{abstract}

Keywords: Bacterioplankton; Continental shelf; KEEP; Kuroshio; POC; $Q_{10}$

* Corresponding author. Tel.: 011-886-2-2364-0919; fax: 011-886-2-2364-0919.

E-mail address: frank@odb03.gcc.ntu.edu.tw (F.-K. Shiah) 


\section{Introduction}

Heterotrophic bacterioplankton (bacteria) are currently believed to be important agents of carbon cycling in aquatic ecosystem, since they are the major (or perhaps the only) organisms responsible for the consumption of biogenic organic carbon (see Ducklow and Carlson, 1992; Fuhrman, 1992 for review). Several studies have suggested that many biological systems are probably the net source of $\mathrm{CO}_{2}$ due to bacterial activities (Findlay et al., 1991; Smith and Hollibaugh, 1993; del Giorgio et al., 1997). Bacterial production have been investigated in many parts of the world oceans, but such data in the shelf area of the western Pacific, particularly the East China sea, are rarely available until recently.

Although, on area basis, the continental shelves constitute about $10 \%$ of the world oceans (Liu et al., 1998), these ecosystems could be very important in affecting global carbon cycling due to large standing stocks of particulate organic carbon (POC) and high rates of primary production (PP). The East China Sea (ECS) has one of the largest shelves in the world. Four different water types have been identified that affect the hydrography of the southern part of the ECS. They are the China Coastal Waters (the CCW), the oligotrophic Taiwan Strait Waters (the TSW), the upwelled Kuroshio Subsurface Waters (the KSW) and the oligotrophic Kuroshio Waters (the KW). In this area there are two major inorganic nutrient sources: one from river discharges on the east coast of Mainland China and the other from the Kuroshio upwelling occurs at the shelf break north-east of Taiwan (Gong et al., 1996). High rates of PP and concentrations of POC in the CCW and the KSW have been reported (Liu et al., 1995; Shiah et al., 1996; Gong et al., this issue). It is believed that the complicated hydrography caused by the interactions of different water types in the shelf area might ultimately affect the spatial patterns of PP, POC and thus bacterial activities.

The major purpose of this study was to understand spatial variability of bacterial biomass, production and turnover rates in the shelf area of the southern ECS in spring and autumn seasons. Their relationships with PP, POC and hydrographic data were analyzed to explore possible controlling mechanisms. Bacterial carbon fluxes and their potential roles in carbon cycling in the ECS shelf were also discussed at the end of this report.

\section{Materials and methods}

\subsection{Study area and sampling}

This study was performed at the five stations along a transect across the shelf of the southern East China Sea north of Taiwan (Fig. 1). A total of four cruises were conducted during either spring or autumn season; they were Cruises 386 (May 1994), 405 (Nov 1994), 414 (Mar 1995) and 449 (Apr 1996). Seawater was collected from a SeaBird CTD-General Oceanic Rosette assembly with 201 Go-Flo bottles. Light intensity was measured with a PAR sensor (QSP200L; Biospherical Inc.) and the depth of the euphotic-zone was defined as $1 \%$ of the surface light penetrated. All 


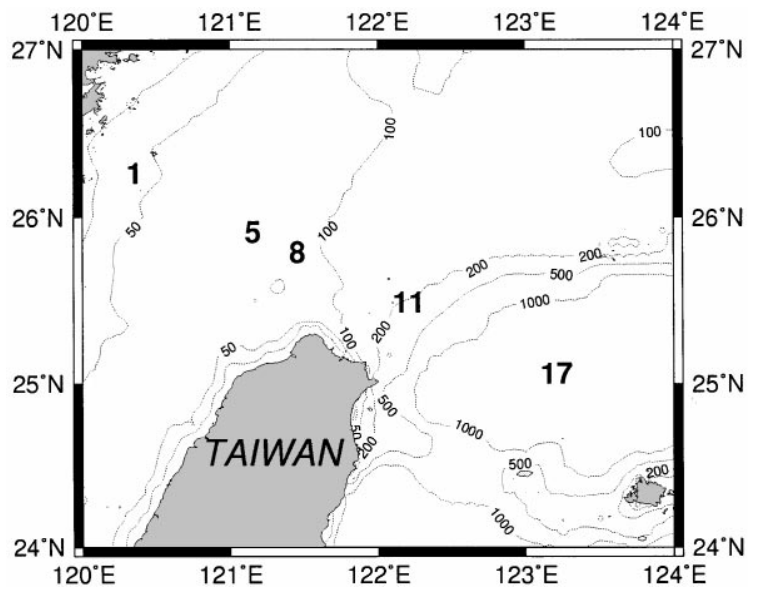

Fig. 1. Map of the southern East China Sea showing sampling stations. Values on dashed lines indicate bottom depth in meter.

measurements described below were conducted before dawn with samples taken from the same cast.

\subsection{Primary productivity}

Primary production was measured by the ${ }^{14} \mathrm{C}$ assimilation method (Parsons et al., 1984). In brief, three light and one dark $250 \mathrm{ml}$ clean polycarbonate bottles were filled with water which pre-screened through $200 \mu \mathrm{m}$ mesh to remove large zooplankton and detritus and then inoculated with $\mathrm{H}^{14} \mathrm{CO}_{3}^{-}$(final conc., $10 \mu \mathrm{Ci} \mathrm{ml}{ }^{-1}$ ). One light bottle was filtered immediately as the time-zero sample. Incubation was performed by in situ method proposed by Barber (1993) with some modifications. Two light and one dark bottles for each depth were in turn tethered onto the in situ array. The array with a $50 \mathrm{~kg}$ sinker attached at the bottom, was lowered down to the water column such that the samples would be situated at their original depth. A $50 \mathrm{~m}$ tag line connected to the top of the array was tied to the stern of the research vessel.

Following retrieval at dusk, the bottles were stored in the dark and processed immediately. The water samples were filtered through Whatman $25 \mathrm{~mm} \mathrm{GF} / \mathrm{F}$ filters with pumping pressure $<100 \mathrm{mmHg}$. The filters then were placed in scintillation vials and $0.5 \mathrm{ml}$ of $0.5 \mathrm{~N} \mathrm{HCl}$ was added to remove residual $\mathrm{H}^{14} \mathrm{CO}_{3}^{-}$. Radioactivity was counted in a liquid scintillation counter (Packard 1600) after addition of $10 \mathrm{ml}$ scintillation cocktail (Ultima Gold, Packard) into vials.

\subsection{Particulate organic carbon}

Water samples $(0.5 \sim 2.01)$ for particulate organic carbon (POC) measurement were filtered through $200 \mu \mathrm{m}$ mesh to remove zooplankton and then Whatman 
$25 \mathrm{~mm} \mathrm{GF} / \mathrm{F}$ filters. After filtration, samples were wrapped in aluminium foil and stored at $4^{\circ} \mathrm{C}$. Both filters and aluminium foil were pre-combusted at $550^{\circ} \mathrm{C}$ for $1 \mathrm{~h}$ before filtration processes. POC concentrations were measured by $\mathrm{CHN}$ analyzer (Fisons; NA1500) after samples were dried and acid-fumed.

\subsection{Bacterial abundance and production}

Bacterial abundance was determined by using the acridine orange direct count method (Hobbie et al., 1977). Samples fixed with glutaraldehyde (final conc., 1\%) were stained with acridine orange (final conc., $0.01 \%$ ) and then filtered through $0.2 \mu \mathrm{m}$ polycarbonate filters prestained with Irgalan black solution. Slides were enumerated by epifluorescence microscopy (Zeiss, Axioplan). Biomass was calculated with a carbon conversion factor of $2 \times 10^{-14} \mathrm{~g}$ cell $^{-1}$. Bacterial production was estimated by ${ }^{3} \mathrm{H}$-thymidine (Fuhrman and Azam, 1982) incorporation with a conversion factor of $1.18 \times 10^{18}$ cells mol thymidine ${ }^{-1}$. Triplicates $40 \mathrm{ml}$ aliquots of water samples were incubated with ${ }^{3} \mathrm{H}$-[methyl]-thymidine (Sp. activity., $6.7 \mathrm{Ci} / \mathrm{mmol}$; final conc., $20 \mathrm{nM}$ ) in clean polycarbonate tubes in the dark at in situ temperature. Reaction was stopped by adding formaldehyde (final conc., $1 \%$ ). The killed samples including time zero controls were filtered through $0.2 \mu \mathrm{m}$ cellulose nitrate filters. Filters were rinsed three times each with ice-cold 5\% trichloroacetic acid and ice-cold $80 \%$ ethyl alcohol sequentially. Scintillation cocktail ( $6 \mathrm{ml}$; Ultima Gold, Packard) was added after dried filters were dissolved completely in $0.5 \mathrm{ml}$ of ethyl acetate. Radioactivity was determined by liquid scintillation (Packard 1600). Bacterial turnover rates were calculated by dividing bacterial production by bacterial biomass.

\subsection{Chlorophyll-a and nitrate concentrations}

Chlorophyll-a and nitrate concentrations were measured following the methods of Parsons et al. (1984). Water samples for nutrients analysis were frozen immediately with liquid nitrogen after collection. Nitrate was analyzed with a self-designed flow injection analyzer (Gong, 1992) and was reduced to nitrite with a cadmium wire which activated with a copper sulphate solution. For chlorophyll-a, 2.51 of seawater were filtered through $47 \mathrm{~mm} \mathrm{GF} / \mathrm{F}$ filters which then stored immediately at $-20^{\circ} \mathrm{C}$. Back at the laboratory, the filters were ground in $10 \mathrm{ml} 90 \%$ acetone followed by extraction in a $4^{\circ} \mathrm{C}$ shaking incubator for $2 \mathrm{~h}$. After centrifugation at $1000 \mathrm{rpm}$ for $5 \mathrm{~min}$, concentrations of chlorophyll in the supernatant were measured on a Turner fluorometer (model 10-AU-005). Phytoplankton biomass was calculated by a conversion factor of $58 \mathrm{mgC} \mathrm{mg}$ chlorophyll ${ }^{-1}$ (Eppley et al., 1992).

\section{Results}

\subsection{Hydrography}

The sampling stations encompassed the inner and outer shelf of the southern East China Sea. The depth of the euphotic zone was very shallow $(<40 \mathrm{~m})$ at Sts. 1 and 5 
and increased to $>75 \mathrm{~m}$ at St. 17 (Table 1). Generally, salinity and temperature increased seaward from Sts. 1 to 17 within each cruise (Figs. 2(A) and (B)). However, the local temperature minimum $\left(20-22^{\circ} \mathrm{C}\right)$ observed at St. 11 marked the area where upwelling occurred (see also below). Individual nitrate ( $\mathrm{iNO}_{3}^{-}$; Table 1) and the euphotic-zone integrated nitrate $\left(\mathrm{INO}_{3}^{-}\right.$; Fig. $2(\mathrm{C})$ concentrations were always higher at coastal (St. 1) and the upwelling (St. 11) areas and showed an opposite trend with temperature and salinity; the upper water column at St. 17 was depleted of $\mathrm{iNO}_{3}^{-}$on all cruises. In summary, St. 1 was typical coastal water characterized by high $\mathrm{iNO}_{3}^{-}$, low temperature and low salinity, while St. 17 represented typical oligotrophic warm oceanic waters with high salinity ( $>34.4 \mathrm{psu}$ ). The copious $\mathrm{iNO}_{3}^{-}$concentrations and low temperature observed in the surface water at St. 11 indicated that there was a source of nutrient supply via upwelling processes in this area (Liu et al., 1992b).

Of these 5 stations, Sts. 11 and 17 were relatively more stable than others, in terms of hydrography or biological activities (see below). These characters varied dramatically at Sts. 1, 5 and 8, depending on the magnitude of mixing between different water types and, perhaps, biological activities (i.e. uptake of $\mathrm{NO}_{3}^{-}$by phytoplankton). For examples, on Cruise 405, the water at Sts. 5 and 8 probably was more affected by the warm oligotrophic and high salinity TSW than the CCW, as indicated by warmer temperature, higher salinity and much lower $\mathrm{INO}_{3}^{-}\left(<50 \mathrm{mmol} \mathrm{m}^{-2}\right)$. On Cruise 414, the situation reversed and St. 5 was more likely to be influenced by the CCW, which resulted in high $\mathrm{INO}_{3}^{-}\left(196 \mathrm{mmol} \mathrm{m}{ }^{-2}\right)$. The same argument could be applied to St. 8 on Cruises 386 and 405 . The upwelling center off northern Taiwan persisted all year, whereas its position might change with time (Liu et al., 1992a; Gong et al., 1997). We suspected that the water at St. 8 was more likely to have been affected by the TSW and KSW on Cruises 386 and 405, respectively. These results suggested that water characteristics at the same sampling station could be quite variable among different cruises and this in fact provided a good opportunity to examine the coupling among physical, chemical and biological phenomena.

\subsection{Phytoplankton biomass, primary production and POC concentrations}

Individual phytoplankton biomass (iPB; $6-177 \mathrm{mgC} \mathrm{m}^{-3}$ ) varied about 30-fold among stations (Table 1). Higher values of the euphotic-zone integrated phytoplankton biomass (IPB) were observed at coastal and upwelling areas, while the values of IPB at St. 17 were all less than $1000 \mathrm{mgC} \mathrm{m}^{-2}$ (data not shown). Depth profiles of individual primary production (iPP; $0.2-139 \mathrm{mgC} \mathrm{m}^{3} \mathrm{~d}^{-1}$; Table 1) at each sampling station showed similar trends with higher values in the surface water and then decreased with depth. The euphotic-zone integrated primary production (IPP) were high at Sts. 1,8 and 11 , with values $>750 \mathrm{mgC} \mathrm{m}^{-2} \mathrm{~d}^{-1}$, while IPP recorded at Sts. 5 and 17 were low with average values $<500 \mathrm{mgC} \mathrm{m}^{-2} \mathrm{~d}^{-1}$ (Fig. 2(D)).

The depth profiles of individual POC concentrations (iPOC; $10-210 \mathrm{mgC} \mathrm{m}^{-3}$ ) and spatial patterns of the euphotic-zone integrated POC (IPOC; 1415-4682 $\mathrm{mgC} \mathrm{m}^{-2}$; Fig. 2(E)) were pretty much the same as iPP and IPP, respectively. 

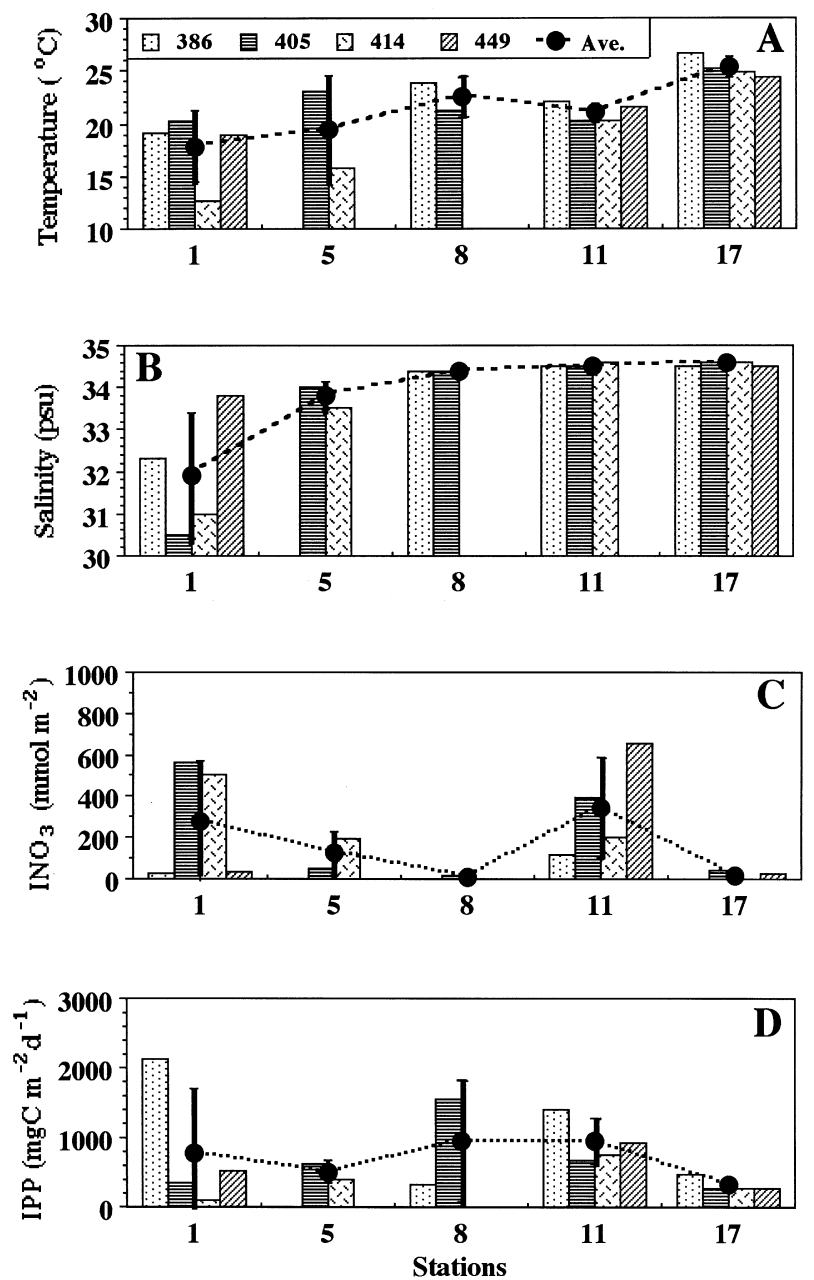

Fig. 2. The euphotic-zone averaged (closed circles) and integrated (columns) values of measured variables. Vertical bars indicate standard errors. (D), IPP: integrated primary production; (E), IPOC: integrated particulate organic carbon; (F), IBB: integrated bact. biomass; (G), IBP: integrated bact. production and $(\mathrm{H})$, bact. turnover rates $=\mathrm{IBP} / \mathrm{IBB}$.

\subsection{Bacterial biomass, production and turnover rates}

Individual bacterial biomass (iBB) ranged $2.2-50.4 \mathrm{mgC} \mathrm{m}^{-3}\left(0.11-2.5 \times 10^{9}\right.$ cells $1^{-1}$; Figs. 3(A)-(D)) with most of the higher values $\left(>30 \mathrm{mgC} \mathrm{m}^{-3}\right)$ recorded at coastal stations. $\mathrm{BBB}$ at these stations were high at the surface, decreased with depth and then slightly increased at depths near the bottom. In the oligotrophic $\mathrm{KW}$, iBB seldom exceeded $10 \mathrm{mgC} \mathrm{m}^{-3}$ except on Cruise 449 with iBB ranged 

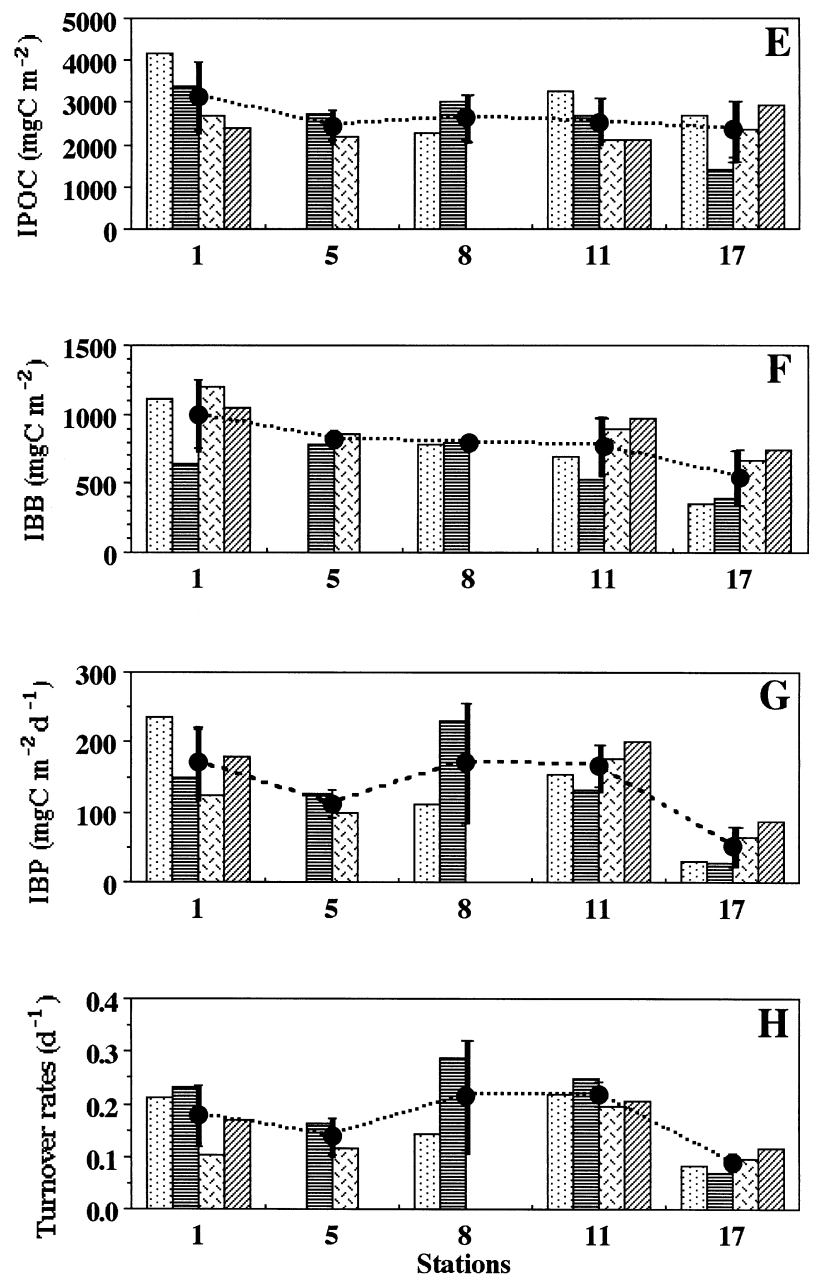

Fig. 2. (Continued.)

$10.8-17.0 \mathrm{mgC} \mathrm{m}^{-3}$ in the upper $30 \mathrm{~m}$ (Fig. 3(C)). iBB of upwelling stations usually were lower and higher than coastal and Kuroshio stations, respectively.

Individual bacterial production (iBP) varied $>60$-fold with values ranged $0.22-13.9 \mathrm{mgC} \mathrm{m}^{-3} \mathrm{~d}^{-1}$ (Figs. 4(A)-(D)). Depth profiles of iBP of all sampling stations showed the same trend with higher values at the surface and then decreased with depth. On each cruise, the highest and the lowest iBP were always recorded at the coastal surface waters and the Kuroshio deep water $(>50 \mathrm{~m})$, respectively. On Cruise 405 , iBP of St. 8 ranked the highest among all stations (Fig. 4(C)) and this might be related with high values of IPOC and IPP (Figs. 2(D)-(E)). On Cruise 414, iBP were all low, particularly for the coastal waters $\left(<4.5 \mathrm{mgC} \mathrm{m}^{-3} \mathrm{~d}^{-1}\right.$; Fig. $\left.4(\mathrm{C})\right)$ which were 
Table 1

A list of the ranges of measured variables ${ }^{a}$ derived from the four cruises conducted at the East China Sea north of Taiwan

\begin{tabular}{lrlllllll}
\hline Cruise & Sts. & $\begin{array}{l}\mathrm{Ze} \\
(\mathrm{m})\end{array}$ & $\begin{array}{l}\text { Temp } \\
\left({ }^{\circ} \mathrm{C} \pm \mathrm{SD}\right)\end{array}$ & $\begin{array}{l}\text { Salinity } \\
(\mathrm{psu} \pm \mathrm{SD})\end{array}$ & $\begin{array}{l}\mathrm{NO}_{3}^{-1} \\
(\mu \mathrm{M})\end{array}$ & $\begin{array}{l}\mathrm{POC} \\
\left(\mathrm{mgC} \mathrm{m}^{-3}\right)\end{array}$ & $\begin{array}{l}\mathrm{PB} \\
\left(\mathrm{mgC} \mathrm{m}^{-3}\right)\end{array}$ & $\begin{array}{l}\mathrm{PP} \\
\left(\mathrm{mgC} \mathrm{m}^{-3} \mathrm{~d}^{-1}\right)\end{array}$ \\
\hline 386 & 1 & 40 & $19.12 \pm 0.35$ & $32.345 \pm 1.220$ & $0.2 / 1.0$ & $56 / 210$ & $18 / 177$ & $10 / 139$ \\
& 8 & 60 & $23.90 \pm 0.01$ & $34.427 \pm 0.012$ & $<0.2$ & $28 / 82$ & $6.4 / 17$ & $1.2 / 31$ \\
& 11 & 75 & $22.00 \pm 2.69$ & $34.476 \pm 0.110$ & $<0.2 / 1.9$ & $17 / 81$ & $13 / 55$ & $1.2 / 93$ \\
& 17 & 75 & $26.74 \pm 0.62$ & $34.547 \pm 0.095$ & $<0.2$ & $30 / 52$ & $9.3 / 14$ & $2.9 / 11.4$ \\
405 & 1 & 40 & $20.28 \pm 0.31$ & $30.523 \pm 0.478$ & $12.9 / 15.8$ & $57 / 127$ & $11 / 77$ & $1.2 / 32.9$ \\
& 5 & 40 & $23.09 \pm 0.01$ & $33.990 \pm 0.001$ & $1.2 / 1.5$ & $51 / 104$ & $23 / 32$ & $6.2 / 28.4$ \\
& 8 & 60 & $21.18 \pm 1.45$ & $34.420 \pm 0.024$ & $<0.2 / 9.1$ & $18 / 113$ & $5.8 / 169$ & $0.4 / 96.6$ \\
& 11 & 75 & $20.17 \pm 0.62$ & $34.482 \pm 0.029$ & $3.4 / 6.6$ & $27 / 56$ & $9.9 / 59$ & $0.2 / 51.8$ \\
& 17 & 75 & $25.18 \pm 0.16$ & $34.627 \pm 0.023$ & $<0.2 / 1.1$ & $15 / 25$ & $8.7 / 13$ & $0.3 / 10.2$ \\
414 & 1 & 40 & $12.74 \pm 0.40$ & $31.024 \pm 0.607$ & $11.1 / 16.0$ & $60 / 100$ & $13 / 31$ & $0.3 / 17.0$ \\
& 5 & 40 & $15.75 \pm 0.16$ & $33.510 \pm 0.016$ & $4.1 / 6.7$ & $23 / 88$ & $11 / 61$ & $0.2 / 44.5$ \\
& 11 & 75 & $20.31 \pm 1.44$ & $34.644 \pm 0.033$ & $1.9 / 3.5$ & $10 / 55$ & $7.0 / 45$ & $1.2 / 38.6$ \\
& 17 & 75 & $24.91 \pm 0.00$ & $34.630 \pm 0.002$ & $<0.2 / 2.3$ & $16 / 49$ & $10 / 16$ & $0.8 / 7.0$ \\
449 & 1 & 40 & $19.02 \pm 1.49$ & $33.826 \pm 0.458$ & $<0.2 / 1.6$ & $21 / 145$ & $5.8 / 50$ & $0.4 / 34.4$ \\
& 11 & 75 & na & na & $4.5 / 12.6$ & $9 / 70$ & na & $0.6 / 54.2$ \\
& 17 & 75 & $24.44 \pm 0.06$ & $34.527 \pm 0.043$ & $<0.2 / 3.3$ & $32 / 52$ & na & $0.7 / 5.5$ \\
\hline
\end{tabular}

${ }^{a}$ Ze: depth of the euphotic zone; POC: particulate organic carbon; PB: phytoplankton biomass ( = Chl$\mathrm{a} \times 58$ ) and PP: primary productivity. SD: standard deviation and na, not available.

much lower than those recorded on other three cruises. The values of coefficient of determination (i.e. $\left.R^{2}\right)$ for iBP vs. iPOC were $>0.63(p<0.01$; Fig. 5$)$. Noted that the four slope values $(0.10-0.19)$ for iBP vs. iPOC did not vary much among cruises.

Individual bacterial turnover rates $(\mathrm{i} \mu=\mathrm{iBP} / \mathrm{iBB})$ ranged $0.03-0.45 \mathrm{~d}^{-1}$ (Figs. 6(A)-(D)). In general, values of bacterial i $\mu$ were higher at the depths less than $40 \mathrm{~m}$ of all stations; some, but not all, of the i $\mu$ profiles decreased exponentially with depth. On each cruise, spatial variations of the i $\mu$ was quite significant; the $i \mu$ in the CCW and the KSW $\left(>0.22 \mathrm{~d}^{-1}\right)$ were at least 2 -fold of those recorded in the KW $\left(<0.09 \mathrm{~d}^{-1}\right)$. Noted that on Cruise 414 (Fig. 6(C)), bacterial i $\mu$ in the CCW (i.e. Sts. 1 and 5) were exceptionally low $\left(<0.13 \mathrm{~d}^{-1}\right)$ and this might be due to low temperature (Table 1).

Euphotic-zone integrated bacterial biomass (IBB; Fig. 2(G)), integrated bacterial production (IBP; Fig. 2(H)) and averaged bacterial turnover rates $(\mu=\mathrm{IBP} / \mathrm{IBB}$; Fig. 2(I)) all showed the same patterns with higher values appeared in coastal and upwelling areas. Table 2 revealed the correlation among the euphotic-zone integrated variables. Correlation analysis with all individual data was almost exactly the same as that with euphotic-zone integrated data (data not shown). Nitrate concentrations $\left(\mathrm{INO}_{3}^{-}\right)$showed negative trends with temperature and salinity. All biological variables were positively correlated with each other except IBB, which was negatively 

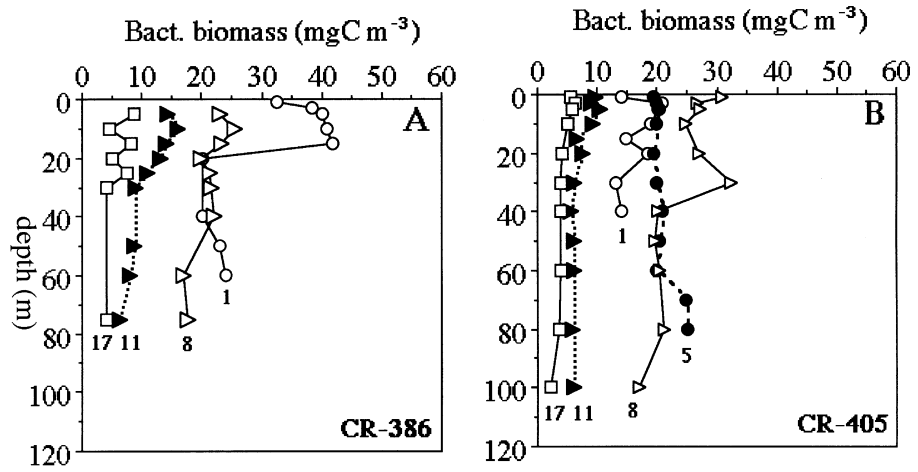

Bact. biomass $\left(\mathrm{mgC} \mathrm{m}^{-3}\right)$

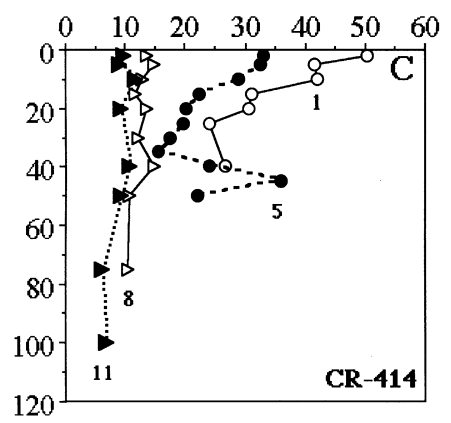

Bact. biomass $\left(\mathrm{mgC} \mathrm{m}^{-3}\right)$

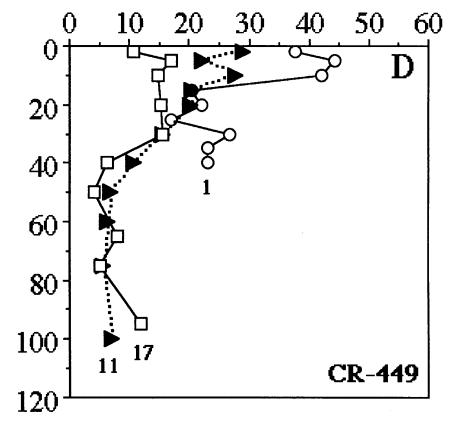

Fig. 3. Depth profiles of bacterial biomass measured on the four cruises. Numerical numbers below symbols represent sampling stations.

correlated with temperature and salinity. Bacterial rate parameters (IBP and $\mu$ ) were positively correlated with other biological variables (IPOC, IPB and IPP) but showed no correlation with temperature, salinity as well as nitrate concentrations. As the two low temperature $\left(<16^{\circ} \mathrm{C}\right.$; Cruise 414 , Sts. 1 and 5) data removed from correlation analysis, temperature became negatively correlated with all other variables while $\mathrm{INO}_{3}^{-}$was positively correlated with $\mu$ (Table 3). Figs. 7(A) and (B) clearly showed that above $20^{\circ} \mathrm{C}$ (the outer shelf area), IBP and $\mu$ decreased as temperature increased; temperature alone explained 76 and $62 \%$ of the spatial variance of IBP and $\mu$, respectively. Note also that in the outer shelf area, the spatial patterns of IBP (and $\mu$ ) during spring (Cruises 386, 414 and 449) and fall (Cruise 405) were quite similar in term of their relationships to temperature. One interesting phenomenon was that IBP and $\mu$ taken from the inner shelf area $\left(12-20^{\circ} \mathrm{C}\right)$ increased with the rise of temperature, indicating a possibility of temperature controlled (see more in discussion).

Ratios of IBB:IPB (18-186\%) at most stations were $<70 \%$ with three exceptions; they were $186 \%$ at St. 1 on Cruise $414,114 \%$ at St. 1 on Cruise 449 and $146 \%$ at 
Bact. production $\left(\mathrm{mgC} \mathrm{m}^{-3} \mathrm{~d}^{-1}\right)$

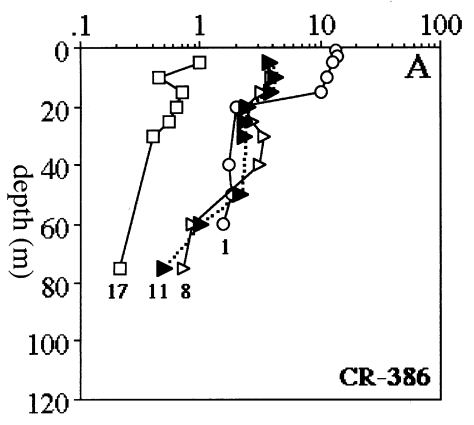

Bact. production $\left(\mathrm{mgC} \mathrm{m}^{-3} \mathrm{~d}^{-1}\right)$

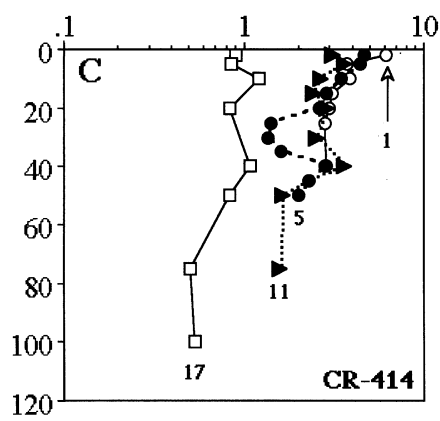

Bact. production $\left(\mathrm{mgC} \mathrm{m}^{-3} \mathrm{~d}^{-1}\right)$

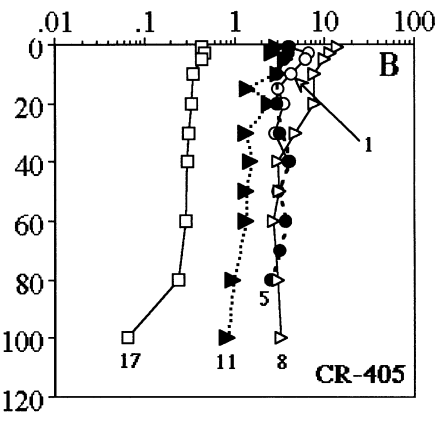

Bact. production $\left(\mathrm{mgC} \mathrm{m}^{-3} \mathrm{~d}^{-1}\right)$

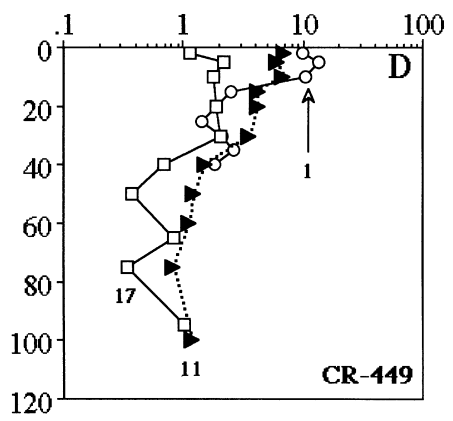

Fig. 4. The same as Fig. 3, but for bacterial production. Note the $X$-axis are in log scale for better presentation and the $X$-axis scale of panel $\mathrm{C}$ is different from panels A, B and D.

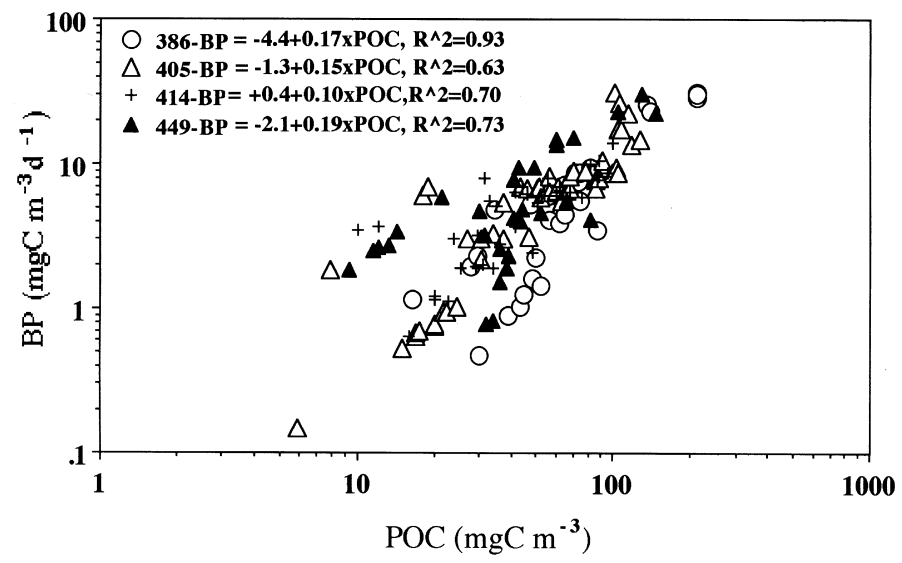

Fig. 5. Scatter plot of POC concentrations vs. bacterial production for the 4 cruises. 
Bact. turnover rate $\left(\mathrm{d}^{-1}\right)$

Bact. turnover rate $\left(\mathrm{d}^{-1}\right)$
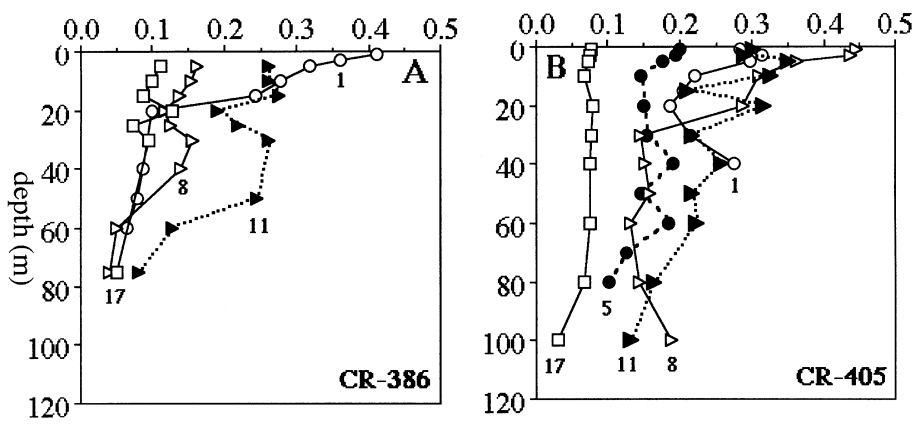

Bact. turnover rate $\left(\mathrm{d}^{-1}\right)$

Bact. turnover rate $\left(\mathrm{d}^{-1}\right)$
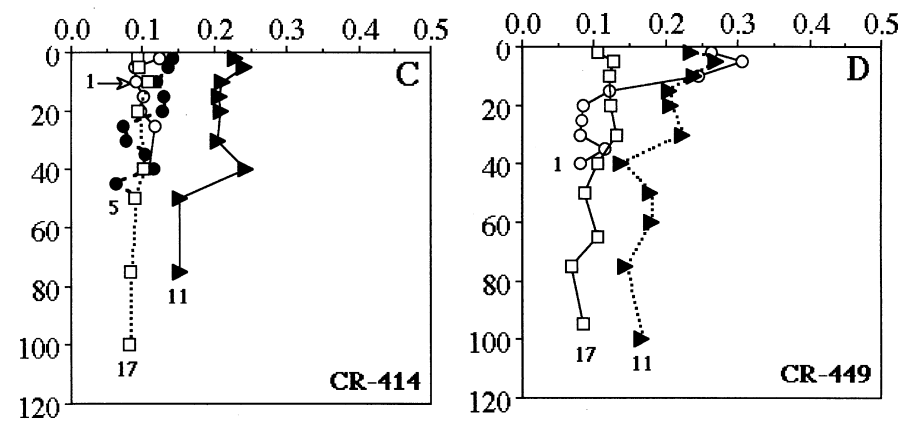

Fig. 6. The same as Fig. 3, but for bacterial turnover rates.

Table 2

Correlation coefficients $(r)^{\mathrm{a}}$ among measured variables with euphotic-zone integrated data. $T$ and Sal were euphotic-zone averaged values

\begin{tabular}{lcclccccc}
\hline & $T$ & Sal & $\mathrm{INO}_{3}$ & IBB & IBP & Bact $\mu$ & IPOC & IPB \\
\hline Sal & +0.63 & $* * * * *$ & & & & & & \\
$\mathrm{INO}_{3}$ & -0.61 & -0.71 & $* * * * *$ & & & & & \\
IBB & -0.76 & -0.46 & - & $* * * * *$ & & & & \\
IBP & -0.45 & - & - & +0.65 & $* * * * *$ & & & \\
Bact $\mu$ & - & - & - & na & na & $* * * * *$ & & \\
IPOC & - & -0.49 & - & - & +0.64 & +0.59 & $* * * * *$ & \\
IPB & - & - & - & - & +0.65 & +0.75 & +0.57 & $* * * *$ \\
IPP & - & - & - & - & +0.73 & +0.64 & +0.71 & +0.80 \\
\hline
\end{tabular}

${ }^{\text {a }}$ Significant at $p=0.01$.

St. 8 on Cruise 386. Values of IBP:IPP ratio (6-42\%) were $<50 \%$ except at St. 1 on Cruise 414 with a ratio of $138 \%$. Ratios of IBB:IPB and IBP:IPP seemed quite randomly distributed along the sampling transect and were not correlated with any other measured variables. 
Table 3

Same as Table 2 but for stations with mean temperature $>20^{\circ} \mathrm{C}$

\begin{tabular}{lcccccccr}
\hline & $\mathrm{T}$ & Sal & $\mathrm{INO}_{3}$ & $\mathrm{IBB}$ & $\mathrm{IBP}$ & Bact $\mu$ & IPOC & IPB \\
\hline Sal & +0.46 & $* * * * *$ & & & & & & \\
$\mathrm{INO}_{3}$ & -0.44 & -0.59 & $* * * * *$ & & & & & \\
$\mathrm{IBB}$ & -0.72 & - & - & $* * * * *$ & & & & \\
IBP & -0.87 & - & - & +0.82 & $* * * * *$ & & & \\
Bact $\mu$ & -0.79 & - & +0.49 & na & na & $* * * * * *$ & & \\
IPOC & -0.48 & -0.62 & - & +0.42 & +0.63 & +0.59 & $* * * * *$ & \\
IPB & -0.65 & - & - & - & +0.67 & +0.73 & +0.60 & $* * * *$ \\
IPP & -0.50 & - & - & +0.54 & +0.75 & +0.60 & +0.74 & +0.77 \\
\hline
\end{tabular}
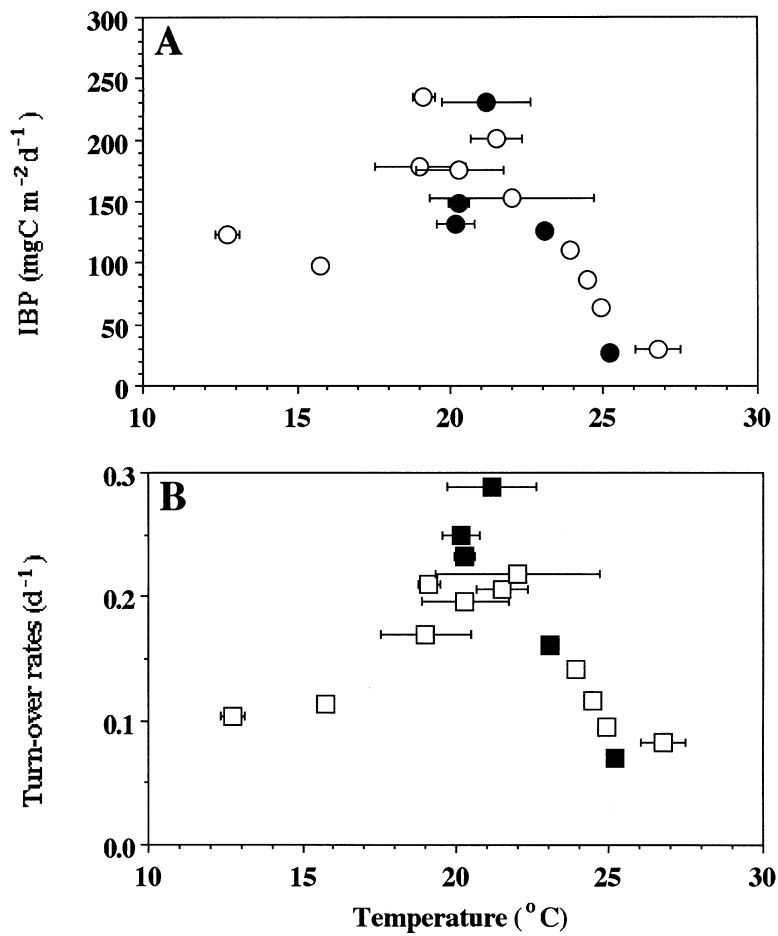

Fig. 7. Scatter plots of integrated bacterial production (A; IBP) and averaged bacterial turnover rates $(\mathrm{B} ;=\mathrm{IBP} / \mathrm{IBB})$ vs. averaged temperature within the euphotic zone. Vertical bars indicate standard error of temperature. Open and closed symbols represent spring (cruises 386, 414 and 449) and fall (cruise 405) data, respectively. 


\section{Discussions}

\subsection{Bacterial spatial patterns}

Bacterial biomass and rate parameters in the shelf area showed distinct spatial patterns, which might be controlled ultimately by the variations of inorganic nutrient supply rate. Within the study area, the major sources of inorganic nutrient $\left(\mathrm{NO}_{3}^{-}\right)$ came from the low temperature $\left(<20^{\circ} \mathrm{C}\right) \mathrm{CCW}$ and $\mathrm{KSW}$. In these two areas, high $\mathrm{NO}_{3}^{-}$supply rates might elevate IPB and IPP which indicated high supply rates of dissolved organic matter required for bacterial growth (Cole et al., 1988) as long as temperature was optimal (see below). On the other hand, the warm $\left(>24^{\circ} \mathrm{C}\right)$ and nutrient-depleted $\mathrm{KW}$ constituted the other end member which was characterized by low IPB and IPP in the study area. Noted that from Sts. 11 to 17, IPB, IPP dropped more than $50 \%$ with a negligible decrease in IPOC (Figs. 2(D)-(F)). We were not able to explain such phenomenon but to point out this controversy.

Grazing (top-down control), substrate supply rates (bottom-up control) and temperature have been proposed as the three major factors in regulating bacterial production in aquatic environments. However, their relative importance might be system dependent and controlling factors might interactively affect bacterial properties at different temporal and spatial scales. Sanders et al. (1992) suggested that bottom-up control was more important in oligotrophic environments. Other studies have showed that bottom-up and top-down processes might shift rapidly in days (Psenner and Sommaruga, 1992) and the strength of bottom-up control might be influenced by the change in temperature (Ducklow, 1992; Shiah and Ducklow, 1994).

Our results revealed some evidences of substrate supply effects on the spatial patterns of bacterial properties, particularly for the outer shelf area. The positive correlation observed among bacterial rate parameters and IPOC, IPP and IPB (Table $3)$ indicated a high possibility of bottom-up control. Another evidence came from the good correlation between $\mathrm{BP}$ and $\mathrm{BB}$. It has been proposed that at steady state, the utilization of substrate by bacteria should be very close to substrate supply rate. Thus, a significant correlation between $\log _{10} \mathrm{iBP}$ and $\log _{10} \mathrm{iBB}(r=+0.86, n=153$, $p<0.01$ ) should be good evidence for bottom-up control (Billen et al., 1990; Ducklow, 1992; Shiah and Ducklow, 1994).

The final evidence derived from the results shown in Figs. 7(A) and (B). Within the study area, temperature seemed to be a good tracer for different water types during spring and fall (Fig. 2(A)); it might also reflect the magnitude of the supply rates of inorganic nutrient (Gong et al., 1995) and dissolved organic substrates (Tables 2 and $3)$. Therefore, the inverse relationship found between IBP (and $\mu$ ) and temperature particularly in the range of $21-25^{\circ} \mathrm{C}$, might be viewed as an extra evidence suggesting that bacterial spatial patterns were determined by the variations of substrate supply rates which were resulted from the spatial changes of hydrography.

The low bacterial $\mu$ observed the inner shelf area $\left(<20^{\circ} \mathrm{C}\right.$; Fig. $\left.7(\mathrm{~B})\right)$ might be ascribed to a direct physiological inhibition by low temperature. In this study, bacterial $\mu$ increased exponentially from 12 to $22^{\circ} \mathrm{C}$ and this gave a $Q_{10}$ (the increase in the turnover rate for each $10^{\circ} \mathrm{C}$ increase in temperature $)$ value of $3.12\left(R^{2}=0.88\right.$, 
$n=8, p<0.01$ ). One might ask whether the bacterial $\mu$ vs. temperature relationship derived from our transect-study is applicable to the whole (or most of the) shelf area. In another study conducted in May 1996 which cover broader area of the shelf $\left(25-30^{\circ} \mathrm{N} ; 120.0-125.5^{\circ} \mathrm{E}\right.$; Shiah et al., 1999) showed that for the $<20^{\circ} \mathrm{C}$ data, the $Q_{10}$ value for bacterial turnover rate was $3.30\left(R^{2}=0.77, n=27, p<0.01\right)$. These similar findings suggested that temperature might play a more dominant role than the rate of substrate supply in the inner shelf area; however, for the outer shelf area, the situation might reverse. Many studies have demonstrated that bacterial $\mu$ could be reduced by low temperature at a time scale of hours irrespective of substrate supply rates (Shiah and Ducklow, 1994; Kirchman et al., 1995). Low temperature might also reduce PP and thus algal exudation rates. This might in turn diminish the availability of substrate for bacterial growth and lead to low bacterial $\mu$ and production. Bacterivory is also a function of temperature (Marrase et al., 1992), higher IBB recorded at Sts. 1 and 5 on Cruise 414 might be due to low grazing rates induced by low temperature. However, we have not had any bacteriovores data up to present, therefor, it was quite difficult to analyze the top-down effects. Overall, these results supported our speculation that changes of hydrography over the shelf area were probably the ultimate cause resulting in the spatial variability of bacterial biomass and turnover rates.

\subsection{Bacterial carbon flux}

The fates of biogenic particulate and dissolved organic carbon (i.e. POC and DOC) within the euphotic zone is one of the important issues of the KEEP project. The major difficulty in evaluating bacteria importance in the ocean carbon system lies in the uncertainties of factors converting thymidine incorporation rates and biomass (thymidine and carbon conversion factors; TCF and $\mathrm{CCF}$ ) into carbon based units. In addition, bacterial growth efficiency (BGE) which is required in estimating bacterial carbon demand also varies. Together, TCF and CCF may vary more than three order of magnitude and BGE can be in the range of $<5 \%->80 \%$ (Ducklow and Carlson, 1992). To avoid over-estimation, lower published values of TCF $\left(1.18 \times 10^{18}\right.$ cell mole $\mathrm{TdR}^{-1}$; Fuhrman and Azam, 1982) and CCF (20 fg cell ${ }^{-1}$; Ducklow and Carlson, 1992) were used here. Another drawback of this study is that we used the same TCF and $\mathrm{CCF}$ across different water masses and seasons and there is a possibility that these conversion factors, including chlorophyll to carbon ratios may varied with seasons and water masses.

The grand averages of IBP, IPP, IBB and IPB over the shelf were $138 \pm 77 \mathrm{mgC} \mathrm{m}^{-2} \mathrm{~d}^{-1}, 695 \pm 562 \mathrm{mgC} \mathrm{m}^{-2} \mathrm{~d}^{-1}, 821 \pm 294 \mathrm{mgC} \mathrm{m}^{-2}$ and $1572 \pm$ $913 \mathrm{mgC} \mathrm{m}^{-2}$, respectively. Ratios of IBP:IPP were in the range of $6-42 \%$ with an average of $22 \pm 10 \%$. Assuming a BGE of $20 \%$ (del Giorgio et al., 1997), we estimated that bacteria might consume carbon equivalent to almost $100 \%$ of the in situ daily particulate primary production within the euphotic zone. The exudation of DOC (i.e. dissolved organic carbon) from primary production was probably insufficient to sustain such a high bacterial carbon demand. This indicates that other sources of DOC, such as excretion from non-bacterial planktoners, POC dissolution and 


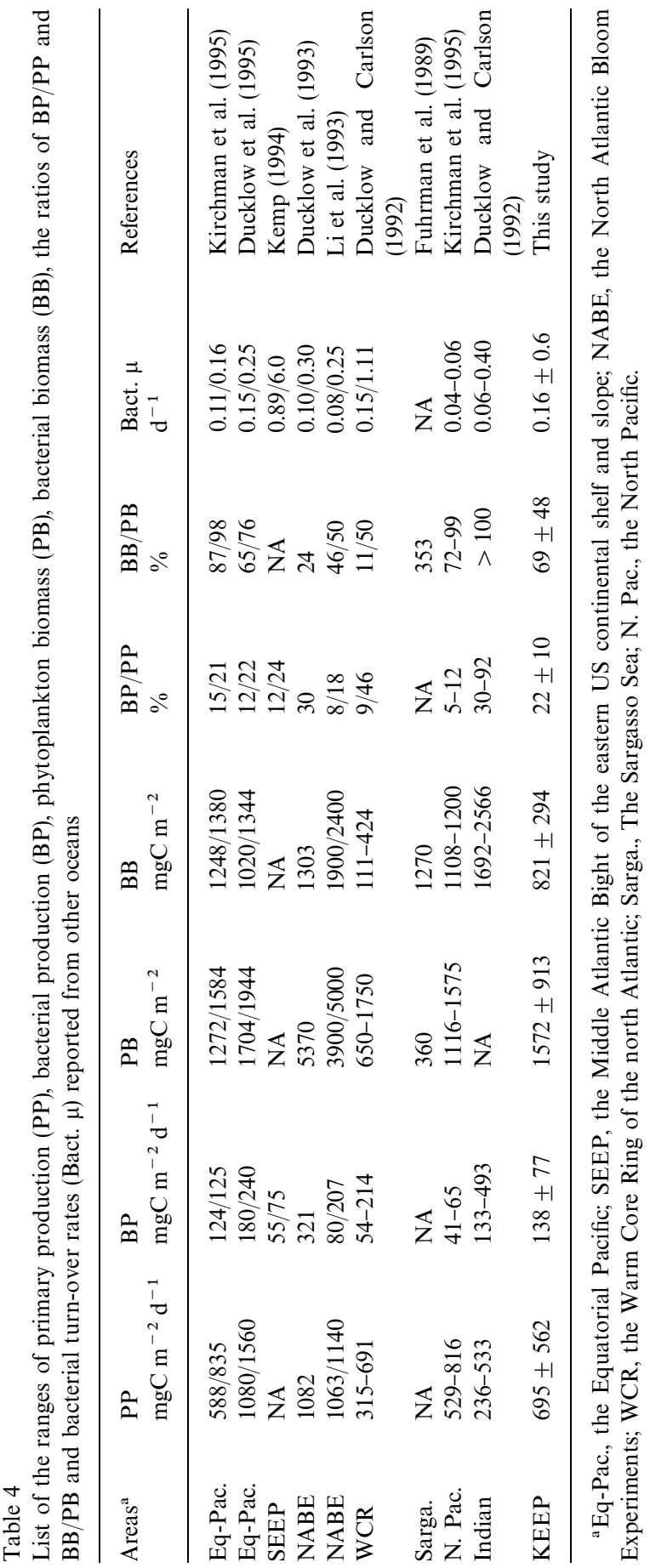


allochothonous DOC, were probably important in supporting bacterial carbon demand in the shelf area. Previous studies showed rich supply of DOC from riverine discharges and remobilization of surficial sediments in the ECS (Cauwet and Mackenzie, 1993). The high DOC concentration in the KW was also a possible source of the allochothonous DOC (Hung and Lin, 1994; Hung et al., this issue).

When compared with the data from other Oceans, ratios of IBP:IPP seldom exceeded $50 \%$ in many aquatic ecosystems (Table 4; see also Ducklow and Carlson, 1992 for more examples); the global value of IBP:IPP is about 30\% (Cole et al., 1984). Of the 16 sampling stations, only one data (St. 1, Cruise 414) showed an extremely high ratio of $138 \%$. As pointed out by Ducklow et al. (1993), higher ratios of IBP:IPP (i.e. $>60 \%$ ) suggested that either BP was supported principally by non-phytoplankton DOC sources or the system was at non-steady state. We preferred the second explanation based on the followed reasons. Values of IPP $\left(90 \mathrm{mgC} \mathrm{m}^{-2} \mathrm{~d}^{-1}\right)$ and phytoplankton turnover rates $\left(0.14 \mathrm{~d}^{-1}\right)$ were remarkably low, when compared with those recorded at the same station on other cruises $\left(>350 \mathrm{mgC} \mathrm{m}^{-2} \mathrm{~d}^{-1}\right.$; $>0.50 \mathrm{~d}^{-1}$ ); this could be ascribed to either the rather low temperature or sun-light intensity (Gong et al, this issue) or both. On the other hand, IPOC $\left(2678 \mathrm{mgC} \mathrm{m}^{-2}\right.$ ) was not particularly lower than other cruises $\left(2405-4181 \mathrm{mgC} \mathrm{m}^{-2}\right)$. We suspected that bacterial activity was probably out of phase with that of phytoplankton during sampling and this might result in an unusually high ratio.

The values of IBB:IPB ratio at three stations were $>100 \%$, while others varied from 36 to $73 \%$. Many studies have shown that IBB surpassed IPB in some oceanic areas (Table 4). In the Sargasso sea, Fuhrman et al. (1989) showed a IBB:IPB ratio of $>350 \%$ and argued that the dominance of IBB over IPB is possible when bacterial $\mu$ was lower than phytoplankton $\mu$. This idea was supported by Ducklow and Carlson (1992), who reviewed the data collected from different Ocean areas. The same conclusion was also evident from our data (Fig. 8), which indicated that as the ratio of bacterial $\mu$ : phytoplankton $\mu$ increased, IBB:IPB ratios decreased at a logarithmic scale $(r=-0.58, n=12, p<0.05)$.

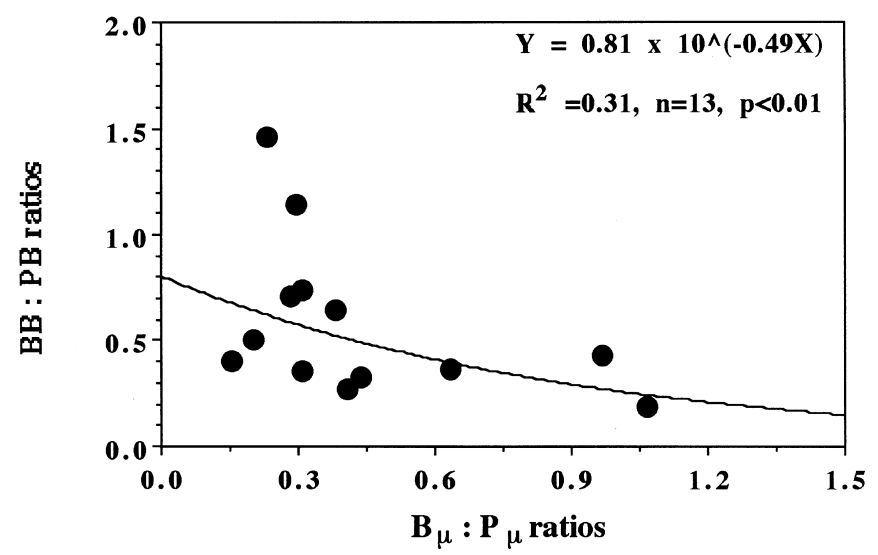

Fig. 8. Scatter plot of biomass ratios of bacteria:phytoplankton vs. turnover rate ratios of bacteria:phytoplankton. 


\section{Conclusions}

Bacterial biomass, production and turnover rates in the shelf area of the southern East China Sea showed distinct spatial patterns during spring and fall. Such spatial variations could be related to the particular hydrographic conditions of different water types. Coastal and upwelling waters were characterized by low temperature and high concentrations of inorganic nutrients. The rich supply of nutrients usually enhanced primary production and POC concentrations, which might in turn replenish the dissolved organic matter required for bacterial growth. With conservative assumptions, we found that the in situ particulate primary production could barely meet bacteria carbon demand in the shelf area. This indicated that non-phytoplankton sources of dissolved organic matter might be important in supporting bacterial carbon demand. In addition, allochothonous dissolved organic matter might be needed to fulfil the bacterial carbon demand.

\section{Acknowledgements}

NCOR contribution paper \# 9. Support for this research was provided by the National Science Council, Taiwan, ROC. The valuable comments for this manuscript from two anonymous reviewers are deeply appreciated. We thank the crew of the R/V Ocean Researcher I for cruise assistance.

\section{References}

Barber, R.T., 1993. In situ primary productivity protocol. In: Kadar, S., Leinen, M., Murray, J.W., (Eds.), U.S. JGOFS Equatorial Pacific Processes Study Sampling and Analytical Protocols. pp. $12-14$.

Billen, G., Servais, P., Becquevort, S., 1990. Dynamics of bacterioplankton in oligotrophic and eutrophic aquatic environments: bottom-up or top-down control? Arch. Hydrobiologia. Beih 207, 37-42.

Cauwet, G., Mackenzie, F.T., 1993. Carbon inputs and distribution in estuaries of turbid rivers: the Yang Tze and Yellow rivers (China). Marine Chemistry 43, 235-246.

Cole, J.J., Findlay, S., Pace, M.L., 1988. Bacterial production in fresh and saltwater ecosystems: a crosssystem overview. Marine Ecology Progress Series 43, 1-10.

del Giorgio, P.A., Cole, J.J., Cimblerist, A., 1997. Respiration rates in bacteria exceed phytoplankton production in unproductive aquatic systems. Nature 385, 148-151.

Ducklow, H.W., 1992. Factors regulating bottom-up control of bacteria biomass in open ocean plankton communities. Arch. Hydrobiologia. Beih 37, 207-217.

Ducklow, H.W., Carlson, C.A., 1992. Oceanic bacterial production. In: Marshall, K.C. (Ed.), Advance in Microbial Ecology. Plenum, New York, pp. 113-181.

Ducklow, H.W., Kirchman, D.L., Quinby, H.L., Carlson, C.A., Dam, H.G., 1993. Stocks and dynamics of bacterioplankton carbon during the spring bloom in the eastern North Atlantic ocean. Deep-Sea Research 40 (1/2), 245-264.

Ducklow, H.W., Ouinby, H.L., Carlson, C.A., 1995. Bacterioplankton dynamics in the equatorial Pacific during the 1992 El Nino. Deep-Sea Research 42 (2-3), 621-638.

Eppley, R.W., Chavez, F.P., Barber, R.T., 1992. Standing stocks of particulate carbon and nitrogen in the equatorial Pacific at $150^{\circ}$ W. Journal of Geophysical Research 97 (C1), 655-661. 
Findlay, S., Pace, M.L., Lints, D., Cole, J.J., 1991. Weak coupling of bacterial and algal production in a heterotrophic ecosystem: the Hudson River estuary. Limnology and Oceanography 36 (2), 268-278.

Fuhrman, J.A., 1992. Bacterioplankton roles in cycling of organic matter: the microbial food web. In: Falkowski, P.G., Woodhead, A.D. (Eds.), Primary Productivity and Biogeochemical Cycles in the Sea. Plenum, New York, pp. 361-383.

Fuhrman, J.A., Azam, F., 1982. Thymidine incorporation as a measurement of heterotrophic bacterioplankton production in marine surface waters: evaluation and field results. Marine Biology 66, 109-120.

Fuhrman, J.A., Sleeter, T.D., Carlson, C.A., Proctor, L.M., 1989. Dominance of bacterial biomass in the Sargasso Sea and its ecological implications. Marine Ecology Progress Series 57, 207-217.

Gong, G.-C., 1992. Chemical hydrography of the Kuroshio front in the sea northeast of Taiwan. Ph.D. Thesis, Institute of Oceanography, National Taiwan University. Taiwan, ROC.

Gong, G.-C., Chen, Y.-L.L., Liu, K.-K., 1996. Chemical hydrography and chlorophyll distribution in the East China Sea in summer: implications in nutrient dynamics. Continental Shelf Research 16, 1561-1590.

Gong, G.-C., Liu, K.-K., Pai, S.-C., 1995. Prediction of nitrate concentration from two end member mixing in the southern East China Sea. Continental Shelf Research 15, 827-842.

Gong, G.-C., Shiah, F.-K., Liu, K.-K., Chuang, W.-S., Chang, J., 1997. Effect of Kuroshio intrusion on the chlorophyll distribution in the southern East China sea north of Taiwan during Spring, 1993. Continental Shelf Research 17, 79-94.

Hobbie, J.E., Daley, R.J., Jasper, S., 1977. Use of nuclepore filters for counting bacteria by fluorescence microscopy. Applied Environmental Microbiology 33 (5), 1225-1228.

Hung, J.J., Lin, P.L., 1994. Distribution of dissolved organic carbon in the continental margin off northern Taiwan. Terrestrial, Atmospheric and Oceanic Sciences 6, 13-26.

Kemp, P.F., 1994. Microbial carbon utilization on the continental shelf and slope during the SEEP-II experiment. Deep-Sea Research II 41 (2/3), 563-582.

Kirchman, D.L., Rich, J., Barber, T., 1995. Biomass and biomass production of heterotrophic bacteria along $140^{\circ} \mathrm{W}$ in the equatorial Pacific: effects of temperature on the microbial loop. Deep-Sea Research II 42 (2-3), 603-619.

Li, W.K.W., Irwin, B.D., Dickie, P.M., 1993. Dark fixation of 14C: variations related to biomass and productivity of phytoplankton and bacteria. Limnology and Oceanography 38 (3), 483-494.

Liu, K.-K., Gong, G.-C., Lin, S., Yang, C.-Y., Wei, C.-L., Pai, S.-C., Wu, C.-K., 1992a. The year-round upwelling at the shelf break near the northern tip of Taiwan as evidenced by chemical hydrography. Terrestrial, Atmospheric and Oceanic Sciences 3, 243-275.

Liu, K.-K., Gong, G.-C., Shyu, C.-Z., Pai, S.-C., Wei, C.-L., Chao, S.-Y., 1992b. Response of Kuroshio upwelling to the onset of northeast monsoon in the sea north of Taiwan: observations and a numerical simulation. Journal of Geophysical Research 97, 12 511-12 526.

Liu, K.-K., Iseki, K., Chao, S.-Y., 1998. Continental margin carbon fluxes. In: Hanson, R.B., Ducklow, H., Field, J.G. (Eds.), The Changing Ocean Carbon Cycle. Cambridge University Press., Cambridge pp. 187-239.

Liu, K., Lai, Z., Gong, G., Shiah, F., 1995. Distribution of particulate organic matter in the southern East China sea: implications of production and transport. Terrestrial. Terrestrial, Atmospheric and Oceanic Sciences 6 (1), 27-46.

Marrase, C., Lim, E.L., Caron, D.A., 1992. Seasonal and daily changes in bacterivory in a coastal plankton community. Marine Ecology Progress Series 82, 281-289.

Parsons, T.R., Maita, Y., Lalli, C.M., 1984. In: A Manual of Chemical and Biological Methods for Seawater Analysis. pergamon, New York, pp. 173.

Psenner, R., Sommaruga, R., 1992. Are rapid changes in bacterial biomass caused by shifts from top-down to bottom-up control. Limnology and Oceanography 37 (5), 1092-1100.

Sanders, R.W., Caron, D.A., Berninger, U., 1992. Relationships between bacteria and heterotrophic nanoplankton in marine and fresh waters: an inter-ecosystem comparison. Marine Ecology Progress Series $86,1-14$. 
Shiah, F., Ducklow, H.W., 1994. Temperature regulation of heterotrophic bacterioplankton abundance, production, and specific growth rate in Chesapeake Bay. Limnology and Oceanography 39 (6), $1243-1258$.

Shiah, F., Gong, G., Liu, K., 1996. Light effects on phytoplankton photosynthetic performance in the southern East China Sea north of Taiwan. Botanical Bulletin of Academia Sinica 37, 133-140.

Shiah, F., Gong, G., Kao, S., Liu, K., 1999. Temperature vs. substrate limitation of heterotrophic bacterioplankton production across trophic and temperature gradients in the East China Sea. Aquat. Micro. Ecol. 17 (3), 247-254.

Smith, S.V., Hollibaugh, J.T., 1993. Coastal metabolism and the oceanic organic carbon balance. Review of Geophysics 31 (1), 75-89. 